\title{
Kimberlites and related rocks of Anabar region (Yakutia, Russia)
}

Leluyh, M.I. ${ }^{1}$, Kostrovitsky, S.I. ${ }^{2}$, Bezborodov, S.M., ${ }^{,}$Nikulin, V.I.., ${ }^{3}$, Prokopev, S.A. ${ }^{1}$, Serov, V.P. ${ }^{1}$, Tolstov, A.V. ${ }^{1}$, Zuev V.M. ${ }^{1}$

1 - Almazy Rossii-Sakha Co. Ltd. Mirny, Yakutia, Russia

2 - Institute of Geochemistry, SB RAS, Irkutsk, Russia

3 - Sib. Institute Geol., Geophys. \& Mineral Raw Materials, Irkutsk, Russia

In the North of the Yakutian kimberlite province there is the Anabar diamond-bearing region including arc-like zone of kimberlite volcanism with submeridional orientation, $30-50 \mathrm{~km}$ wide and about $300 \mathrm{~km}$ in extent. The zone is located in the junction zone of the Anabar anteclise and and Lena-Anabar trough (Fig. 1). Geologically the region is built of rocks of the Archean metamorphic complex cut by the intrusive and ultrametamorphic formations of different age and acid, basic and ultrabasic composition. On the periphery of the shield there are carbonate and terrigenous deposits of the Upper Proterozoic, Cambrian, Lower Jurassic and Cretaceous age. The thickness of the sedimentary cover in the zone of occurrence and related rocks does not at present exceed some hundred meters.

The zone consists of the following fields extending from the south to the north, e.g. Kuronakh, Luchakansk, Djuken, Ari-Mastakh, Starorechinsk, Orto-Iargin. In the north of the Starorechinsk field there is the Nomokhtookh site rich in pipe bodies (over 40 pipes). The exploration work indicated the boundaries between the fields to be indistinct or absent at all. The Anabar zone is nearly a continuous band of the Lower Mesozoic kimberlite volcanism. The total of kimberlite bodies is 160 , many of them not outlined, their forms and dimensions determined from magnetic sounding. The main part of kimberlite volcanic pipes has dimensions $20 \times 10-100 \times 50$, some of them achieving 400x300. The dike and veins extend from some tens to hundreds meters, in some cases 1-2 km, with the thickness ranging from 5 to $10 \mathrm{~m}$. The majority of bodies have been found within the carbonate and terrigenous cover of the Anabar massif, some bodies occurring in the crystalline massif. It was revealed that the spatial distribution of kimberlite fields and individual bodies (within fields) are much influenced by the deep-seated fault zones.

The age of kimberlites is considered (Brakhfogel, 1984) to be Middle Triassic - Early Jurassic. The absolute age of kimberlites defined by different methods varies from 188-238 Ma (Rb-Sr method) and 223-242+4 Ma (after zircon by Rb-Sr method) to 246+10 Ma (K-Ar40 method, Maisky pipe).

In the Anabar zone, different authors distinguished along with kimberlites the carbonatites (Marshintsev, 1974; Kornilova et al., 1983), picritic poprhyrites (Milashev, 1974; Ilupin et al., 1978), alnoites (Kornilova et al., 1983). While producing the classification of rocks the researchers included the following characteristics: for carbonatite it was predominance in mesostasis of calcite, for picrite porphyrite - absence of pyrope and picroilmenite phenocrysts and development in groundmass of titanomagnetite and perovskite, for alnoite - presence of montichellite and melilite as the main minerals of rock along with olivine. In this communication we have applied this classification although the authors doubt its correct application.

The proportion of different types of rocks in kimberlite fields is different - from south to north the amount of porphyrites, alnoites as well as carbonatites increased. While the southern Kuranakh field predominantly consists of kimberlites, the extreme northern fields (Starorechinsk Nomokhtokh site and Orto-Iargin) are formed by porphyrites and carbonatites. Alnoite is mostly often found in Djuken, Ari-Mastakh and Starorechinsk fields.

The Lower Mesozoic kimberlites and related rocks of the Anabar area are close in the features of the petrochemical composition to spatially conjugate Middle Paleozoic kimberlites and 
related rocks of the northern fields of the Yakutian province and significantly differ from diamondbearing kimberlites of the Middle Paleozoic localized in the southern part of the province. The Kuronakh field is an exception for its spatial vicinity to diamond-bearing Middle Paleozoic is accompanied by similiarity to the latter of petrochemical compositions of kimberlites, at least in majority of pipe bodies. In general, kimberlites and alneites of the Anabar area show very high abundances of mafic and alkaline components, as well as Al2O3 and P2O5.The content of some oxides (Ti02 3-6 wt\%, K2O 2-5 wt\% and P2O5 1-2.4 wt\%) in kimberlites of Anabar exceeds the norms available for classic occurrences of Yakutian and South-African province, and these data wouldn't allow to refer certain rocks to kimberlites. However, the textural and structural features of rocks, mineralogical composition, first of all high saturation in picroilmenite, can be referred to kimberlite rocks.

The high saturation in the carbonate component is the representative trait of kimberlites of the Yakutian province, the Anabar province included. But in contrast to the Middle Paleozoic diamond-bearing kimberlites, in which heightened contents of carbonate components are explained by an intense manifestation of processes of secondary carbonatization, due to the effect of the thick primarily carbonate sedimentary cover, in the Anabar area carbonate has primarily deep-seated endogenous origin. In some pipes of the Djuken field the borehole cores display (i) the process of separation of carbonate liquid from silicate melt as individual globules with their subsequent accumulation and (ii) formation of independent phase (commonly in the upper horizons of pipes). On the other hand, some pipe bodies, particularly frequetly found in Nomokhtokh and Ortho-Iargin fields, are referred to carbonatites (Marshintsev, 1974). However, the primarily clastic form of carbonatite material suggests that these are kimberlite pipes cutting and disintegrating the carbonate bodies occurring at depth. The problem of relationships between kimberlites and carbonatites is open for discussion.

Wide variations and partial overlapping of ranges of composition variability making up kimberlite bodies contribute to steady differences for individual fields indicating zonation of the Anabar belt of kimberlite volcanism occurrence. Kimberlites composing the extreme southern (Kuronakh) and northern (Nomokhtokh and Orto-Iargin) fields are characterized by fairly high content of $\mathrm{MgO}$ and low FeO, TiO2. The central fields of the Anabar belt (Luchakansk Duken, AriMastakh, part of Starorchinsk) are dominated by kimberlites and alnoites with increased $\mathrm{FeO}$ and $\mathrm{TiO} 2$. In the northern direction of the Anabar belt, in kimberlites and alnoites the content of $\mathrm{Na} 2 \mathrm{O}$ gradually increases. The sites Nomokhtokh and Orto-Iargin are made up of the rocks with the carbonate component (to carbonatite appearance) having crucial part and showing the highest content of P2O5.

High coefficient of iron, titanium and alkalis both of the Lower Mesozoic kimberlites and spatially related Middle Paleozoic kimberlites of the northern fields of the Yakutian province is evidently the reflection of (i) metasomatism of the upper mantle rocks occurring within the northern margin of the Siberian platform and (ii) higher level of origination of magmatic chambers and consequently, higher significance of the lithosphere source as compared to asthenosphere in formation of kimberlite melts. The last conclusion is confirmed by isotope investigation of $\mathrm{Sr}$ and $\mathrm{Nd}$ (Kostrovitsky, Morikio, these abstracts).

The Lower Mesozoic kimberlites, as compared to the diamond-bearing Middle Paleozoic kimberlites, demonstrate the higher level of magmatic differentiation which is reflected in higher variations of iron, titanium and alkali oxides. A significant level of correlation between these oxides confirms existence of magmatic trends of differentiation.

\section{References}

Brakhfogel F.F. (1984) Geological aspects of kimberlitic magmatism of the north-east of Siberian platform. Yakutsk, Sib. br. of Acad. Sci., 128p. (in Russian) 
Kornilova V.P., et al, 1983, Atlas of textures of kimberlite rocks. Moscow, Nauka, 159p. (Russian) Milashev V.A., 1974, Kimberlite provinces. St. Petersburg, Nedra, 286 p. (in Russian).

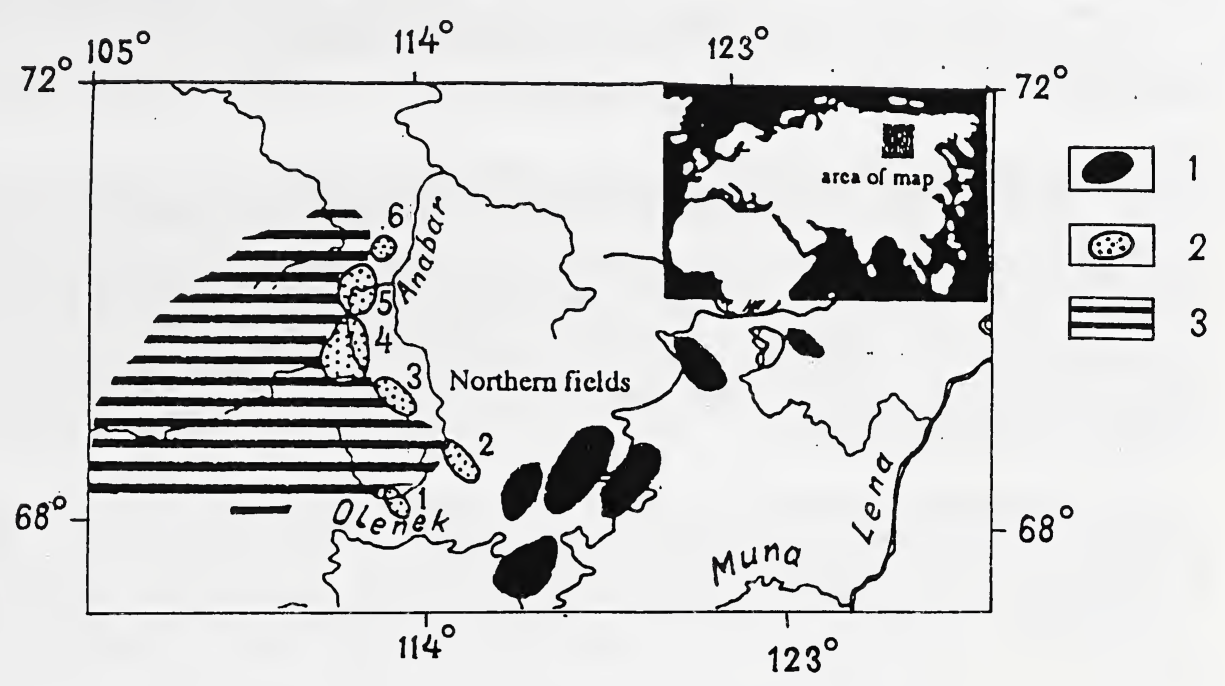

Fig. 1 Map of the Yakutian kimberlite province (Nothern fields).

1) Middle Paleozoic age fields; 2) Mesozoik age fields of the Anabar zone: 1- Kuronakh, 2 - Luchakansk, 3 - Djuken, 4 - Ari-Mastakh, 5 - Starorechinsk, 6 - Orto-Iargin; 3) Precambrian Anabar shield. 